\title{
COMMUNICATIONS
}

\section{TREATMENT OF UVEITIS WITH PYRIMETHAMINE (DARAPRIM) ${ }^{\star}$}

BY

\author{
E. S. PERKINS, C. H. SMITH, P. B. SCHOFIELD, \\ AND
}

Members of the UVeitis Clinic, Institute of Ophthalmology, University of London

AlthOUGH toxoplasmosis was suggested as a cause of congenital choroidoretinitis over 30 years ago, the definite importance of the organism in the acquired disease is still in doubt. The early observations of Janku (1923) and Torres (1927) attracted little attention until Wolf and Cowen (1937) isolated the parasite from a fatal human case. The frequent occurrence of retinitis in the neonatal cases has been confirmed by many authors-for example, Pinkerton and Weinman (1940) and Koch, Wolf, Cowen, and Paige (1943) - and with the development of serological methods, such as the cytoplasm modifying dye test of Sabin and Feldman (1948), it has been possible to assess the importance of the toxoplasma gondii in childhood cases of choroido-retinitis.

Wilder (1952) suggested from a study of histological material that the parasite could be found in certain types of acquired adult choroiditis; her observations have been confirmed by Duke-Elder, Ashton, and Brihaye-Van Geertruyden (1953), and Jacobs and others (1954) have been able to isolate the parasite from an excised eye which had choroiditis.

Unfortunately, these methods of diagnosis can only be used with eyes which have been removed, and any attempts to diagnose the disease by serological methods is complicated by the widespread occurrence of low titre antibodies in normal individuals, but attempt to assess the importance of the infection have been made, notably by Woods, Jacob, Word, and Cook (1954) and by Smith and Ashton (1955). These latter authors, from an analysis of 200 cases, found that a higher proportion of their patients showed antibodies than were present in the normal population. They concluded that, although titre levels were not diagnostic in individual cases, they did show a striking association between toxoplasma infection and posterior uveitis, and they suggested that one of the means of elucidating the exact nature of this relationship might be by means of the response to a specific chemotherapeutic agent.

The most suitable agent for such a trial seemed to be pyrimethamine (Daraprim $\dagger$ (5-(p-chlorphenyl)-2:4-diamino-6-ethylpyrimidine), a drug first introduced for the treatment of malaria. Eyles and Coleman (1953) had first shown it to possess an antitoxoplasmic effect in experimental infections, and this had been confirmed by Summers (1953) and by Trevino, Varela,

\footnotetext{
* Received for publication July 3, 1956

† Burroughs, Wellcome, \& Co.
} 
and Palencia (1953), while Ryan (1954), using the drug in combination with sulphonamides, had reported favourably on its use in cases of uveitis with high serum levels of toxoplasma antibodies. The advantage of this substance in evaluating treatment is that it has a low antibacterial activity and, so far as is known, no effect on allergic conditions; hence any improvement in a case as a result of treatment with this drug will almost certainly be due to its effect on the parasites.

In a preliminary report on the use of Daraprim in uveitis (Smith, 1956) it was shown that mice could be protected from the lethal effects of toxoplasmic infection by Daraprim.

The results in the first 63 cases of uveitis in the clinical trial to be described here were also reported (Perkins, 1956), and it was suggested that some cases with a positive dye test were improving more quickly than untreated cases, although this result was not statistically significant.

A further 101 cases have now been studied and the preliminary results confirmed at a higher level of statistical significance.

\section{Arrangement of Clinical Trial}

Selection of Cases.-We have endeavoured to avoid any bias in selection of cases by including all cases of uveitis showing activity at their first attendance at the Uveitis Clinic at the Institute of Ophthalmology. Some cases have had to be excluded because of difficulty in follow-up or interruption of treatment by intercurrent illness.

At the first visit to the clinic, a careful history is taken and all patients are given a detailed ophthalmological examination. The pathological examinations are initiated and if the condition is active the patient is included in the trial and given tablets, which may contain Daraprim or an inert substance, with instructions to take one each day for 2 weeks. The tablets are labelled A and B, and distributed according to a random list. The clinician in charge of the patient does not know which of the two tablets the patient has received, so that the results cannot be biased by suggestion.

The patient is seen at the end of 2 weeks, and providing no untoward reactions are reported, the treatment is continued for a further 2 weeks. The patient is seen again and the progress of the condition assessed under the headings of visual acuity, degree of injection, aqueous flare, vitreous flare, subjective response, and objective response.

No attempt has been made to assess the degree of improvement, although in some cases this has been very striking. The cases are divided simply into "improved"-in which definite objective signs could be found-and "not improved".

After the assessment of the clinical condition the result was correlated with the toxoplasma reaction and the treatment given. Again it must be emphasized that the person making the assessment did not know whether the patient had received Daraprim or the inert tablets, and in the majority of cases the toxoplasma results were also not yet available. The lack of bias in assessment is clearly shown by the remarkably constant ratio of improved to not improved cases in all groups except those with a positive toxoplasmosis test who received Daraprim. Approximately half of all the cases (except this one group) showed improvement at the end of one month. All the patients received conventional medical treatment, such as mydriatics and cortisone, in addition to the tablets. 
Results.-First it is interesting to compare the percentages of patients showing positive toxoplasma reactions in the three groups of anterior, posterior, and pan-uveitis (Table A); Smith and Ashton (1955) found a similar distribution of complement-fixation test results but rather lower positive dye-test results in each category.

TABLE A

CASES WITH POSITIVE REACTIONS BY CLINICAL CATEGORY

\begin{tabular}{|c|c|c|c|c|c|c|}
\hline \multirow{2}{*}{$\begin{array}{l}\text { Series } \\
\text { of } \\
\text { Cases }\end{array}$} & \multirow{2}{*}{$\begin{array}{l}\text { Clinical } \\
\text { Category }\end{array}$} & \multirow{2}{*}{$\begin{array}{l}\text { Total No. } \\
\text { of Cases }\end{array}$} & \multicolumn{2}{|c|}{ Positive Dye Test } & \multicolumn{2}{|c|}{$\begin{array}{l}\text { Positive Complement- } \\
\quad \text { fixation Test }\end{array}$} \\
\hline & & & Number & Per Cent. & Number & Per Cent. \\
\hline \multirow{3}{*}{$\begin{array}{l}\text { Present } \\
\text { Study }\end{array}$} & Anterior & 98 & 58 & $59 \cdot 2$ & 9 & $9 \cdot 2$ \\
\hline & Posterior & 29 & 23 & $79 \cdot 3$ & 7 & $24 \cdot 1$ \\
\hline & Pan-Uveitis & 37 & 17 & $45 \cdot 9$ & 2 & $5 \cdot 4$ \\
\hline \multirow{3}{*}{$\begin{array}{l}\text { Smith } \\
\text { and } \\
\text { Ashton } \\
\text { (1955) }\end{array}$} & Anterior & 102 & 40 & $39 \cdot 2$ & 8 & $7 \cdot 84$ \\
\hline & Posterior & 31 & 21 & $67 \cdot 7$ & 9 & $28 \cdot 2$ \\
\hline & Pan-Uveitis & 48 & 19 & $39 \cdot 6$ & 7 & $14 \cdot 6$ \\
\hline
\end{tabular}

Davenport (1956), in an analysis of the first 200 cases seen in the Uveitis Clini ${ }_{\mathbf{c}}$ found that the percentage of dye tests (titres of 1 in 4 or over) in age groups up to 59 years was a little over 30 per cent., but that in the age group 60 and over the percentage increased to 58 . A similar analysis of the ages of the patients in this trial is shown in Table B.

Of the 164 cases comprising this series, 98 cases had dye-test titres of 1 in 4 or over, thirty of them having titres of 1 in 4 to 1 in 8 , and the remainder having higher titres. The age and sex distribution of the positive and negative cases is shown in Table C.

TABLE B

AGE GROUPS OF CASES WITH POSITIVE TOXOPLASMA REACTIONS

\begin{tabular}{c|c|c|c}
\hline $\begin{array}{c}\text { Age } \\
\text { Group } \\
\text { (yrs) }\end{array}$ & $\begin{array}{c}\text { No. of } \\
\text { Patients }\end{array}$ & \multicolumn{2}{|c}{ Positive Dye Test } \\
\cline { 2 - 3 } & Number & Per Cent. \\
\hline $1-19$ & 10 & 4 & 40 \\
\hline $20-39$ & 67 & 37 & $55 \cdot 2$ \\
\hline $40-59$ & 68 & 43 & $63 \cdot 2$ \\
\hline $60+$ & 19 & 14 & $73 \cdot 6$ \\
\hline
\end{tabular}

TABLE C

AGE AND SEX DISTRIBUTION OF CASES WITH POSITIVE DYE TESTS

\begin{tabular}{c|c|c|c|c|c|c|c|c|c}
\hline \multicolumn{2}{l|}{ Age Group (yrs) } & \multicolumn{2}{|c|}{$1-19$} & \multicolumn{2}{c|}{$20-39$} & \multicolumn{2}{c|}{$40-59$} & \multicolumn{2}{c}{60 and Over } \\
\cline { 2 - 6 } \multicolumn{2}{l|}{ Result of Dye Test } & Positive & Negative & Positive & Negative & Positive & Negative & Positive & Negative \\
\hline Sex & Male & 0 & 1 & 20 & 18 & 19 & 10 & 6 & 2 \\
& Female & 4 & 5 & 17 & 12 & 24 & 15 & 8 & 3 \\
\hline
\end{tabular}




\section{RESUlTS OF TREATMENT}

The effect of Daraprim on the 66 toxoplasma negative cases will be considered first, as it is important to show whether Daraprim has any nonspecific effect on uveitis; 29 cases received Daraprim and 37 received the control tablets. The results of treatment are shown in Table D; from this it is clear that there is no significant difference between the two groups, and it can be concluded that Daraprim has little effect in cases with a negative toxoplasma reaction.

The group of cases with a positive toxoplasma reaction (as judged by a dye-test titre of 1 in 4 or over) treated with the control tablets shows a very similar improvement rate (Table D) to the treated and untreated cases with a negative toxoplasma reaction.

It is only in the cases with a positive toxoplasma reaction which received treatment with Daraprim that a marked deviation from this improvement

TABLE D

RESULTS OF TREATMENT OF ALL GROUPS

\begin{tabular}{l|l|c|c|c}
\hline \multirow{2}{*}{$\begin{array}{c}\text { Result } \\
\text { of } \\
\text { Dye Test }\end{array}$} & Treatment & \multicolumn{3}{|c}{ Result of Treatment } \\
\cline { 2 - 5 } & Improved & $\begin{array}{c}\text { Not } \\
\text { Improved }\end{array}$ & Total \\
\hline Negative & Control Tablets & 19 & 18 & 37 \\
\cline { 2 - 5 } & Daraprim & 15 & 14 & 29 \\
\hline Positive & Control Tablets & 21 & 21 & 42 \\
\cline { 2 - 5 } & Daraprim & 43 & 13 & 56 \\
\hline
\end{tabular}

TABLE E

ANALYSIS OF RESULTS IN ANTERIOR, POSTERIOR, AND PAN-UVEITIS

\begin{tabular}{|c|c|c|c|c|c|c|}
\hline \multirow{2}{*}{$\begin{array}{c}\text { Toxoplasma } \\
\text { Reaction }\end{array}$} & \multirow{2}{*}{$\begin{array}{l}\text { Clinical } \\
\text { Category }\end{array}$} & \multirow{2}{*}{ Treatment } & \multicolumn{3}{|c|}{ Result of Treatment } & \multirow{2}{*}{$x^{2}$} \\
\hline & & & Improved & $\begin{array}{c}\text { Not } \\
\text { Improved }\end{array}$ & Total & \\
\hline \multirow{3}{*}{ Positive } & Anterior & $\begin{array}{l}\text { Daraprim } \\
\text { Control }\end{array}$ & $\begin{array}{l}25 \\
12\end{array}$ & $\begin{array}{r}8 \\
13\end{array}$ & $\begin{array}{ll}33 & \\
25 & \}\end{array}$ & $3 \cdot 5$ \\
\hline & Posterior & $\begin{array}{l}\text { Daraprim } \\
\text { Control }\end{array}$ & $\begin{array}{r}15 \\
6\end{array}$ & $\begin{array}{l}2 \\
6\end{array}$ & $\left.\begin{array}{l}17 \\
12\end{array}\right\}$ & $3 \cdot 38$ \\
\hline & Pan-Uveitis & $\begin{array}{l}\text { Daraprim } \\
\text { Control }\end{array}$ & $\begin{array}{l}3 \\
6\end{array}$ & $\begin{array}{l}3 \\
5\end{array}$ & $\begin{array}{r}6 \\
11\end{array}$ & \\
\hline \multirow{3}{*}{ Negative } & Anterior & $\begin{array}{l}\text { Daraprim } \\
\text { Control }\end{array}$ & $\begin{array}{l}13 \\
12\end{array}$ & $\begin{array}{l}7 \\
8\end{array}$ & $\begin{array}{l}20 \\
18\end{array}$ & \\
\hline & Posterior & $\begin{array}{l}\text { Daraprim } \\
\text { Control }\end{array}$ & $1^{\circ}$ & $\begin{array}{l}2 \\
1\end{array}$ & $\begin{array}{l}3 \\
3\end{array}$ & \\
\hline & Pan-Uveitis & $\begin{array}{l}\text { Daraprim } \\
\text { Control }\end{array}$ & $\begin{array}{l}1 \\
5\end{array}$ & $\begin{array}{l}5 \\
9\end{array}$ & $\begin{array}{r}6 \\
14\end{array}$ & \\
\hline
\end{tabular}
rate is found; 76 per cent. of the treated cases improved as against 50 per cent. of the control group. Using the $\chi^{2}$ test this difference is found to be significant $\left(\chi^{2}=6 \cdot 4\right.$ $0.01<P<0.02)$. 
As cortisone is known to cause improvement in some cases of uveitis, the cases were analysed with respect to the numbers receiving this drug. However, the proportion of patients receiving this drug did not differ significantly between the toxoplasma positive and negative, treated and untreated groups.

In Table $\mathrm{E}$ these results are analysed into anterior, posterior, and panuveitis, and, although the numbers in each group are too small for the differences to be statistically significant, the figures for the posterior uveitis group ( 88.8 per cent. improved) do suggest that toxoplasmosis is a very likely aetiological agent.

The results of Daraprim treatment in cases with a positive toxoplasma reaction are compared with those in cases with a negative toxoplasma reaction in Table F. Again the difference is statistically significant $\left(\chi^{2}=4 \cdot 4 ; 0.02<\right.$ $P<0.05)$.

The response to treat-

TABLE F

RESULTS OF TREATMENT WITH DARAPRIM IN CASES WITH POSITIVE AND NEGATIVE TOXOPLASMA REACTIONS

\begin{tabular}{l|c|c|c|c}
\hline \multirow{2}{*}{$\begin{array}{c}\text { Toxoplasma } \\
\text { Reaction }\end{array}$} & Treatment & \multicolumn{3}{|c}{ Result of Treatment } \\
\cline { 2 - 4 } & Improved & $\begin{array}{c}\text { Not } \\
\text { Improved }\end{array}$ & Total \\
\hline Positive & Daraprim & 43 & 13 & 56 \\
\hline Negative & Daraprim & 15 & 14 & 29 \\
\hline
\end{tabular}

TABLE G

RESULTS OF TREATMENT ACCORDING TO DYE-TEST TITRE

\begin{tabular}{|c|c|c|c|c|c|c|c|c|}
\hline \multirow[b]{2}{*}{ Treatment } & \multirow{2}{*}{$\begin{array}{l}\text { Result of } \\
\text { Treatment }\end{array}$} & \multicolumn{7}{|c|}{ Dye-Test Titre } \\
\hline & & $\begin{array}{c}1: 4 \\
\text { to } \\
1: 8\end{array}$ & $\begin{array}{c}1: 9 \\
\text { to } \\
1: 16\end{array}$ & $\begin{array}{c}1: 17 \\
\text { to } \\
1: 32\end{array}$ & $\begin{array}{c}1: 33 \\
\text { to } \\
1: 64\end{array}$ & $\begin{array}{c}1: 65 \\
\text { to } \\
1: 128\end{array}$ & $\begin{array}{c}1: 129 \\
\text { to } \\
1: 256\end{array}$ & $\begin{array}{c}1: 257 \\
\text { and } \\
\text { Over }\end{array}$ \\
\hline \multirow{2}{*}{ Daraprim } & Improved & 13 & 9 & 8 & 8 & 3 & 1 & 1 \\
\hline & Not Improved & 3 & 3 & 6 & 0 & 0 & 1 & 0 \\
\hline \multirow{2}{*}{$\begin{array}{l}\text { Control } \\
\text { Tablets }\end{array}$} & Improved & 7 & 5 & 4 & 2 & 1 & 2 & 0 \\
\hline & Not Improved & 7 & 4 & 2 & 4 & 3 & 1 & 0 \\
\hline
\end{tabular}

ment by height of dye-test titre is shown in Table G.

An analysis of thosecases with a positive complement-fixation test in addition to a positive dye test is shown in Table $\mathrm{H}$. It will be seen that the ratio of improved to not improved.is rather higher than the results obtained using the dye test only. 
TABLE I

RESULTS OF TREATMENT IN CASES WITH POSITIVE DYE-TESTS, BY AGE GROUP

\begin{tabular}{cr|c|c|c}
\hline \multirow{2}{*}{$\begin{array}{c}\text { Age Group } \\
\text { (yrs) }\end{array}$} & \multicolumn{3}{|c}{ Result of Treatment } \\
\cline { 2 - 4 } & Improved & $\begin{array}{c}\text { Not } \\
\text { Improved }\end{array}$ & Total \\
\hline $1-19$ & $\cdots$ & 2 & 1 & 3 \\
\hline $20-29$ & $\cdots$ & 21 & 6 & 27 \\
\hline $40-59$ & $\cdots$ & 15 & 6 & 21 \\
\hline 60 and Over & 5 & 0 & 5 \\
\hline
\end{tabular}

A correlation of the improvement rate in treated cases with a positive toxoplasma reaction sug- ‥ gested that the age group 20-39 $\overrightarrow{\overline{\mathrm{C}}}$ years gave a better response than 0 the other groups-21 cases out 흠 of 27 showing improvement (Table I).

The cases have also been ana- के lysed into acute, subacute, and $\stackrel{\vec{\circ}}{.}$ chronic, and the results of treat- $\overrightarrow{\vec{\omega}}$ ment are shown in Table $\mathrm{J}$.

TABLE J

RESULTS OF TREATMENT IN ACUTE, SUB-ACUTE, AND CHRONIC CASES

\begin{tabular}{|c|c|c|c|c|c|c|c|}
\hline \multirow{3}{*}{$\begin{array}{c}\text { Toxoplasma } \\
\text { Reaction }\end{array}$} & \multirow{3}{*}{$\begin{array}{l}\text { Result of } \\
\text { Treatment }\end{array}$} & \multicolumn{6}{|c|}{ Treatment } \\
\hline & & \multicolumn{3}{|c|}{ Daraprim } & \multicolumn{3}{|c|}{ Control Tablets } \\
\hline & & Acute & Sub-acute & Chronic & Acute & Sub-acute & Chronic \\
\hline \multirow{3}{*}{ Positive } & Improved & 29 & 7 & 7 & 11 & 4 & 6 \\
\hline & Not Improved & 9 & 2 & 2 & 7 & 3 & 11 \\
\hline & Total & 38 & 9 & 9 & 18 & 7 & 17 \\
\hline \multirow{3}{*}{ Negative } & Improved & 10 & 2 & 3 & 10 & 4 & \\
\hline & Not Improved & 6 & 1 & 7 & 7 & 2 & 9 \\
\hline & Total & 16 & 3 & 10 & 17 & 6 & 14 \\
\hline
\end{tabular}

As might be expected, the acute cases in the positive toxoplasma untreated group and the treated and untreated negative toxoplasma cases show a better improvement rate than the chronic cases, and in the positive toxoplasma group the difference between the acute treated and untreated cases is not statistically significant. However, the subacute and chronic positive

TABLE K

POSITIVE TOXOPLASMA REACTIONS IN SUB-ACUTE AND CHRONIC CASES

\begin{tabular}{l|c|c|c}
\hline \multirow{2}{*}{ Treatment } & \multicolumn{3}{|c}{ Result of Treatment } \\
\cline { 2 - 4 } & Improved & $\begin{array}{c}\text { Not } \\
\text { Improved }\end{array}$ & Total \\
\hline Daraprim & 14 & 4 & 18 \\
\hline Control & 10 & 14 & 24 \\
\hline$\chi^{2}=4 \cdot 1 ; 0.02<P<0.05$
\end{tabular}

toxoplasma cases taken together (Table K) show a statistically significant difference between treated and untreated subacute and chronic toxoplasma positive cases.

The following conclusions can be drawn from the above results:

(1) Daraprim had no detectable effect on cases with nega- 0 tive toxoplasma dye test. 
(2) Both positive and negative cases showed much the same rate of improvement on control tablets, and this rate was very similar to that obtained in negative cases treated with Daraprim.

(3) Only cases with a positive toxoplasma reaction showed any detectable response to Daraprim.

\section{Discussion}

These results suggest very strongly that toxoplasmosis is an aetiological factor in some 25 per cent. of cases of uveitis with a positive dye test. This in itself is a finding of very great interest and importance but is not of much help in the diagnosis of any individual case.

Detailed consideration of the results of this investigation do, however, give some indication of the criteria which should be adopted for the diagnosis of toxoplasmic uveitis.

The first factors to be considered are the dye test and complement-fixation results. A comparison of the results of treatment in cases having a low dye-test titre (1:4 to $1: 16)$ with those in cases with higher titres (Table L) shows no significant difference in their responses to treatment in the group as a whole. The posterior uveitis group shows some tendency to have a larger number of cases with higher titres.

TABLE L

RESULTS OF TREATMENT IN CASES WITH HIGH AND LOW DYE-TEST TITRES

\begin{tabular}{|c|c|c|c|c|c|}
\hline \multirow{3}{*}{$\begin{array}{l}\text { Clinical } \\
\text { Category }\end{array}$} & \multirow{3}{*}{$\begin{array}{l}\text { Result of } \\
\text { Treatment }\end{array}$} & \multicolumn{4}{|c|}{ Dye-Test Titres } \\
\hline & & \multicolumn{2}{|c|}{$1: 4$ to $1: 16$} & \multicolumn{2}{|c|}{$1: 17$ to $1: 256$} \\
\hline & & Daraprim & $\begin{array}{l}\text { Control } \\
\text { Tablets }\end{array}$ & Daraprim & $\begin{array}{l}\text { Control } \\
\text { Tablets }\end{array}$ \\
\hline \multirow{2}{*}{$\begin{array}{l}\text { All Types of } \\
\text { Uveitis }\end{array}$} & Improved & 22 & 12 & 21 & 9 \\
\hline & Not Improved & 6 & 11 & 7 & 10 \\
\hline \multirow{2}{*}{$\begin{array}{l}\text { Posterior } \\
\text { Uveitis }\end{array}$} & Improved & 6 & 1 & 9 & 2 \\
\hline & Not Improved & 1 & 3 & 1 & 0 \\
\hline
\end{tabular}

It is apparent, therefore, that, except perhaps in the posterior group, a low dye-test titre is as significant as a high titre. This result is rather surprising, but does support the suggestion of Smith and Ashton (1955) that a localized toxoplasmic lesion in the eye may not cause a large rise in serumantibodies.

The results of treatment in cases having a positive complement-fixation test in addition to a positive dye test are shown in Table I, and the numbers, although small, do suggest that a positive complement-fixation test adds to the likelihood of a toxoplasmic aetiology.

Variations in titre of the dye test during treatment have so far shown only 
random variations and it has not been possible to correlate these changes with response to treatment.

As far as the pathological tests are concerned, it is only possible to say that a positive dye test of 1 in 4 or over may indicate toxoplasmosis and a positive complement-fixation test is additional evidence but is not obligatory for the diagnosis.

A consideration of the clinical categories gives more hopeful information. The fact that the first proved toxoplasmic infections were congenital or neonatal choroidal lesions suggests that it is in the group of posterior uveitis cases that the acquired disease would have a predeliction. This is amply confirmed in the present investigation. The group of posterior uveitis cases showed a high incidence of positive dye tests $(79 \cdot 3$ per cent. posterior, 59.2 per cent. anterior) and more than double the percentage of positive complement-fixation tests compared to the anterior uveitis group (24.1 per cent. posterior, $9 \cdot 2$ per cent. anterior), and as previously noted the dye-test titres tended to be higher than in the other groups.

The best response to treatment was also obtained in the posterior uveitis group; although the numbers are too small to show a statistical difference between anterior and posterior groups, it is probably a real difference as shown by the degree of improvement in some of the cases. Although no attempt was made to grade the degree of improvement, some cases showed such marked responses that these were noted; six out of the seventeen cases of posterior uveitis treated with Daraprim were noted as showing markees improvement, as compared with only five out of 33 anterior uveitis cases more than double the percentage.

The typical lesion in the posterior group was an area of focal choroidoretinitis with marked vitreous haze. When the haze cleared sufficiently it was often noted that the active lesion was sited at the periphery of an old patch of healed choroiditis. Hogan (1956) reported that the consensus of clinical opinion at the conference on toxoplasmosis was that the condition could not be diagnosed definitely on clinical grounds. Acute and recurrent large foci of chorio-retinal inflammation with heavy opacification of the vitreous were more characteristic of lesions believed to be toxoplasmic.

The position with regard to this type of case seems quite clear and it is apparent that such cases with a positive dye test should be considered to be due to toxoplasmosis and treated as such unless some other aetiology can be proved. It is of interest in this connection to examine the results in nine of the cases of posterior uveitis which were thought, on clinical grounds, to be associated with tuberculosis: seven out of the nine had positive dye tests, four of these improved on treatment with Daraprim, and none failed to respond; one improved and two failed to improve on control tablets.

The anterior uveitis cases present more of a problem. Nearly 60 per cent. of this group had a positive dye test and 25 out of 33 improved on Daraprim 6 as compared with twelve out of 25 treated with control tablets. This 
difference is not quite significant statistically $\left(\chi^{2}=3 \cdot 5\right)$ but is strongly suggestive, and there seems every likelihood that some of these cases are due to toxoplasmosis. It has not, however, been possible to find any clear correlation between the clinical findings and the toxoplasma results, but it is possible that when larger numbers have been treated some clinical features of the toxoplasmic cases will become apparent.

The last clinical category of generalized uveitis shows the least evidence of toxoplasmosis as an aetiological agent. The percentage of positive dye tests (45.9 per cent.) is, however, probably higher than the normal population, but the response to treatment with Daraprim shows no better result than the control group. It seems unlikely, therefore, that cases of generalized uveitis are due to toxoplasmosis.

An interesting speculation which the results of this investigation arouses is the part toxoplasmosis may play in other diseases of uncertain aetiology. Infection with toxoplasmosis is widespread in the population, as evidenced by the "normal" 25 per cent. or more positive dye tests, yet apart from the rare acute cases in adults and the congenital cases, the organism has never been incriminated in any disease except uveitis. Are some of the conditions traditionally associated with uveitis also due to toxoplasmosis? Such a question cannot be answered from the data available at the moment but might well repay further investigation.

Toxic Effects of Daraprim.-After the first twenty patients had received Daraprim, it was noted that the dose of $25 \mathrm{mg}$. daily was sufficient to depress erythropoiesis in about one-third of the cases; this finding is in contrast to that of Ryan, Hart, Culligan, Gunkel, Jacobs, and Cook (1954), who observed this side-effect only with doses of $75 \mathrm{mg}$. daily, whereas a reduction of dosage to $25 \mathrm{mg}$. resulted in recovery. Subsequently full blood counts were carried out at regular intervals on both the Daraprim and control patients, and the records of 193 cases showed the following results:

Of 113 patients receiving Daraprim, the haemoglobin level dropped more than 5 per cent. in 53 (47 per cent.), 23 of whom showed macrocytes in the blood film. The haemoglobin level of the most severely affected case fell from 100 to 83 per cent. in 3 weeks, the anaemia being of the macrocytic normochromic type. In addition, three of these cases showed a slight fall in the leucocyte count with an absolute neutropenia.

Of seventy control patients receiving an inert substance, not one showed evidence of leucocyte depression, although the haemoglobin level of ten (14.3 per cent.) of them dropped by more than 5 per cent. during the course, but in none was there evidence of macrocytosis.

It is clear, therefore, that Daraprim administration should be accompanied by regular blood examinations in order to detect macrocytic anaemia at an early stage, for if this is found to be progressive it may be wiser to discontinue the course, or alternatively the drug may be given with folic acid, which does 
not apparently interfere with the antitoxoplasma effect of Daraprim. Folic acid was not used in our investigations and the course was discontinued only in the one severe case mentioned above.

SUMMARY

A controlled clinical trial of Daraprim (pyrimethamine) in cases of active uveitis showed:

(1) Daraprim had no detectable effect on the improvement of cases with a negative toxoplasma reaction.

(2) Daraprim exerted a statistically significant effect on the improvement of cases having a positive toxoplasma reaction.

(3) Toxoplasmosis was probably the cause of some 25 per cent. of theo cases having a positive toxoplasmosis reaction.

(4) The best response was obtained in cases of circumscribed choroido-: retinitis.

We are indebted to the clinicians of the Moorfields Westminster and Central Eye Hospital for referring their cases to the Uveitis Clinic, and to Prof. C. P. Beattie and Dr. J. K. A. Beverley for carrying out the toxoplasma tests. We should also like to thank Messrs. Burroughs Wellcome and Co. for supplying the Daraprim used in the trial.

The other members of the Uveitis Clinic whose clinical examinations formed the basis for this? paper were Miss I. Gregory, Mrs. I Watkins, Mr. J. Whitwell, and Drs. J. Lister, K. Citron, and A. Woods.

\section{REFERENCES}

DavenPort, R. C. (1956). Proc. roy. Soc. Med., 49, 19.

Duke-Elder, S., Ashton, N., and BriHaye-VAN GeERTRuyden, M. (1953). British Journalơ Ophthalmology, 37, 321 .

Eyles, D. E., and Coleman, N. (1953). Antibiot. Chemother., 3, 483.

Hogan, M. J. (1956). A.M.A. Arch. Ophthal., 55, 333.

JACOBS, L., COOK, M. K., and WILDER, H. C. (1954). Trans. Amer. Acad. Ophthal. Otolaryng., 요 $58,193$.

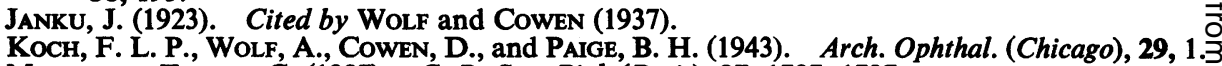

Magarinos Torres, C. (1927). C. R. Soc. Biol. (Paris), 97, 1787, 1797.

Perkins, E. S. (1956). Proc. roy. Soc. Med., 49, 25.

Pinkerton, H., and Weinman, D. (1940). Arch. Path. (Chicago), 30, 374.

Ryan, R. W., Hart, W. M., Culligan, J. J., Gunkel, R. D., Jacobs, L., and Cook, M. K. (1954). Trans. Amer. Acad. Ophthal. Otolaryng., 58, 867.

Sabin, A. B., and Feldman, H. A. (1948). Science, 108, 660.

SMrTH, C. (1956). Proc. roy. Soc. Med., 49, 24.

and Astron, N. (1955). British Journal of Ophthalmology, 39, 545.

Summers, W. A. (1953). Amer. J. trop. Med. Hyg., 2, 1037. 13, 339.

WILDER, H. C. (1952). A.M.A. Arch. Ophthal., 48, 127.

Wolf, A., and CoWEN, D. (1937). Bull. Neurol. Inst. N.Y., 6, 306.

Woods, A. C., JACOBS, L., Wood, R. M., and Cook, M. K. (1954). Trans. Amer. Acad. Ophthal. Otolaryng., 58, 172. 